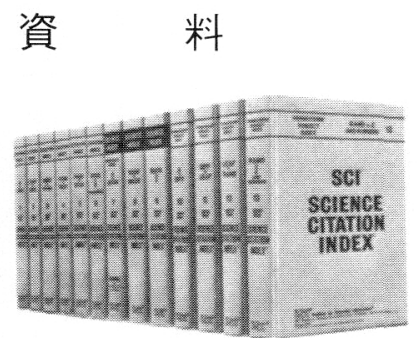

1.は じめに

以前本誌に Science Citation Index (SCI)の紹介を書 いたことがある(1)。これは，米国の institute for Scientific information (iSi, Pennsylvania, USA)が発行してい るもので, 1955年に刊行が開始された。SCI は自然科 学系の汪之んどの学問. 技術分野(農業, 生物, 環境科 学, 工学, 技術, 応用科学, 医学, 生命科学, 物理, 化 学, 行動科学) の主要専門誌(1974年：約2800誌, 1988 年：約3300誌) を source journal として作成された各種 の索引からなっている２ケ月毎にその間の情報をまと めた簡易製本版が発行され，最後に1年分をまとめた ハード・カ・゙ーの annual volumeが出る. 現在では, 1 年分の annual volume だけで大都市の電話帳位の冊子, 20 冊といら大部の索引誌である。

本稿の目的は学術雑誌の評価に関する情報を提供する Journal Citation Reports (SCIの一部として含まれてい る)を紹介することにあるが，前稿を執筆した 15 年前と はSCIの内容もかなり変わってきている点もあるので, SCI 全般についても改めて紹介寸ることにしたい。一部 前稿と重複する部分があることをあらかじめ心断りして おく.

\section{Science Citation Index の概要}

1987年版の Annual volumeの構成は以下の通りであ る.

Vol. $1 \sim 9$ Citation Index

Vol. $10 \quad$ Corporate Index

Vol. 11 13 Source Index

Vol. 14 18 Permuterm Subject Index

* 京都大学教授; 工学部金属加工学科

Introduction to Journal Citation Reports; Masahiro Koiwa (Faculty of Eng., Kyoto Univ., Kyoto

Keywords: science citation index, journal citation reports, ranking of metallurgical journals

1989年 8 月 28 日受理

日本金属学会会報 第28巻 第12号 (1989)
小岩昌 宏*

Vol. 19, 20 Journal Citation Reports

以下, 各索引について説明する。

(1) Citation Index(引用索引，CI)

CI は論文の第一著者名のアルファベット順に記載さ れている、筆者が書いた論文の引用状況を調べた結果を 例示しょら。

KOIWA $M$

65 ACTA METALL 131219 VOL PG YR $\begin{array}{llllll}\text { GABBAY M } & \text { PHYS ST S-A } & 100 & 121 & 87\end{array}$ $\begin{array}{lllll}\text { PALVAL PP PHIL MAG A } & 56 & 407 & 87\end{array}$

66 SCI REP RITU A 18344 $\begin{array}{lllll}\text { HINAI M } & \text { J JPN METAL } & 51 & 1093 & 87\end{array}$ $\begin{array}{lllll}\text { MASUMOTO } \mathrm{H} & \text { " } & 51 & 584 & 87\end{array}$ $\begin{array}{lllll}\text { YOSHINAR O } & \text { J PHYS F } & 17 & 59 & 87\end{array}$

71 PHIL MAG 24107

71 PHIL MAG 24539 $\begin{array}{lllll}\text { OKAMOTO MA ACT METALL } & 35 & 293 & 87\end{array}$

73 PHILOS MAG $26 \quad 173$

$\begin{array}{lllll}\text { SAKAMOTO M } & \text { J PHYS JPN } & 56 & 3201 & 87\end{array}$

74 ACT METALL 221259 $\begin{array}{lllll}\text { KIRCHHEI R } & \text { ACT METALL } & 35 & 271 & 87\end{array}$ $\begin{array}{lllll}\text { LEE JL } & \text { METALL T-A } & 17 & 2183 & 86\end{array}$ $\begin{array}{lllll}\text { MCLELLAN RB } & \text { SCRIP METAL } & 21 & 1263 & 87\end{array}$ $\begin{array}{lllll}\text { PETERSON DT } & \text { METALL T-A } & 18 & 249 & 87\end{array}$ $\begin{array}{llllll}\text { PISAREV AA } & \text { SOV AT EN R R } & 62 & 131 & 87\end{array}$ $\begin{array}{llrrr}\text { TSENG MD } & \text { J LESSC MET } & 136 & 31 & 87 \\ \text { ZHARINOV VP } & \text { FIZ METAL M N } & 64 & 1022 & 87\end{array}$

83 PHILOS MAG A 481 TAHIRKHE RA PHYS REV B $35 \quad 5503 \quad 87$

84 ACTA METALL 32171 $\begin{array}{lllll}\text { FARKAS D } & \text { ACT METALL } & 35 & 353 & 87\end{array}$ $\begin{array}{lllll}\text { OGURA T } & 35 & 1807 & 87\end{array}$

84 PHILOS MAG A 50505 TAHIRKHE RA PHYS REV B $35 \quad 5503 \quad 87$ 84 RES MECHANICA $11 \quad 27$

$85 \mathrm{~J} P H Y S I Q U E \quad 46 \quad 99$ $\begin{array}{llllll}\text { YOSHINAR O } & \text { J PHYS F } & 17 & 59 & 87\end{array}$

以上から，筆者が1965年のActa Metall. 誌に投稿した 論文はPHYS ST S-A 100 (1987) 121 の M. Gabbay の 論文などにより，1966年に東北大のRITUにのせた論 文は 3 つ論文によって引用されている…ㄴ..具 合に，発表年度順に論文が配列され，それぞれの論文を 引用している論文の著者名, 雑誌名, 巻, 頁, 年の順に 記載されている。 
Citation Index においては論文，引用論文のいずれに ついても第 1 著者のみが記されていることに注意する 必要がある。したがって，筆者が共同研究者として名を 連ねている論文の引用状況を知るためには，個々の論文 の第一著者の項を調べる必要がある.

Citation Index の効能としては，たとえば

○科学者が論文発表後，その論文がいかに引用されたか がわかり, 自己の論文の占める位置, その分野の研究 のその後の動向を調べる手がかりがえられる.

○各種財団は研究助成金交付の申込をらけた場合，その 独創性の評価に利用できる。また助成金を交付した研 究がその後どの程度に利用されたかも知ることができ る.

○研究発表後の訂正, 抄録, 翻訳, 論評の有無がわか る。

○原著者の考光ていなかった分野で，そのアイディアが

応用されている事例を調べることができる。

○ある特定の記事が関連部門に及ぼした影響, 研究者の

貢献度合が明らかになる。

○各種専門雑誌の利用度が明らかになる。…などが挙 げられている。

筆者自身の利用経験の具体例として二, 三挙げると

(1)「ポインティング効果」の解説(2)を書いたとき, 1909年，1912年に J. H. Poynting が発表した論文が, 60〜70年を経てどのように引用され評価されているか を調ベた。

（2）相変化の速度論の発表の経緯 (3) を調べた際，M. Avrami の論文の引用状況，ならびに Avrami が “Kinetic Theory of Phase Change” と題する著名な 3 論文以外に ぞんな仕事をしたかを調べた。

（3）筆者が大学院在学中に行った異常塑性余効に関す る研究のその後の展開を調べるために，発表した論文 (Abnormal plastic after-effect in twisted copper, Acta Metall. 13(1965)，673)の引用状況を調べたところ, 数 名の研究者が引用しており，とくにソ連のグループが高 い関心を寄せていることが判明した。

このIndexの弱点は, 姓と名前の initialのみによる 区分をしているために，多数の研究者が一まとめにされ てしまらケースがかなりあることである，原著者自身に とっては自分の論文か否かを判別することはそれほどむ つかしくないかも知れないが，第三者の業績評価などの ために Citation Indexを利用しょらとするとさには大き な障害となる。対象が汪とんど科学の全領域にわってい るので, 同名異人の数はきわめて多い. 山田, 田中, 佐藤, 鈴木, 渡辺，木村……といったありふれた姓の研究者に ついての調査は大変手間がかかる. 欧米人の場合には
D. A. Smith とか J. W. Christianという風に2つまた はそれ以上の名前を持っている人が多いので，同名異人 が一まとめにされる確率は少ないが，通常 1 つの名前 しか持たないわれわれ日本人の場合にはどらしようもな い。この混乱をさけるために，論文発表時には（架空 の? ) middle name をつけている研究者もいる.

\section{(2) Corporate Index (組織索引)}

この索引は Geographic および Organization の 2 つの 部分よりなる. Geographic section では，その年度に論 文を発表(SCI の source journalに)した著者の所属する 研究機関を, 国別さらに都市別にアルファベット順に配 列し, 各研究機関ごとに発表論文の著者名, 誌名, 巻, 頁, 年が列記してある. 表 1 にDepartment of Metal Science and Technology, Kyoto University の部分を例 示する.なお，各論文について第一著者名のみが記され て扣り，必ずしもその著者が当該研究機関に所属してい るとは限らない，共著者の 1 人がその機関に属してい る論文も含まれている。

要するにこの索引は，ある研究機関の論文発表状況と その内訳を調べるのに役立つ. 多くの研究機関ではその 研究活動を PRする冊子や年報に, 研究者の発表論文り ストを揭載している。「論文を発表したら申し出て下さ い」と広報事務担当者がロらるさく依頼しても，つい， らっかりする研究者が多く, 完全なりストを作るのはむ つかしい. Corporate Index を利用すれば，直ちにこの リストを作成することができる。しかし，次の点を配慮 する必要がある。

（1） source journal 以外に発表された論文は揭載され

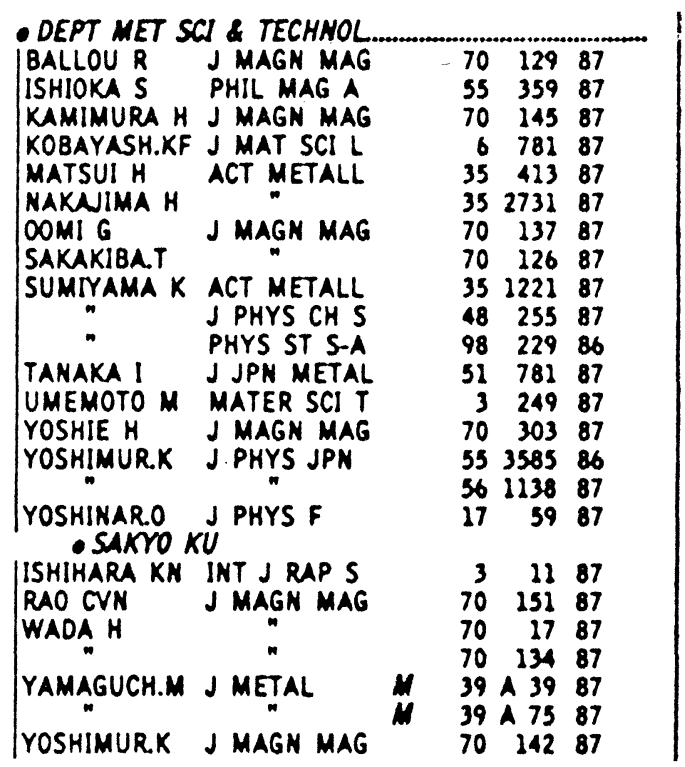

表 1 Corporate Index の例 (京都大学工学部金属加工学科の部分) 
ない(source journal の選定は, 主に impact factor(後 述)などの統計的データにもとついて，iSiの編集委員会 が行っている.iSiの発行するパンフレット, Source Publications for the Science Citation Index に source journalのリストが揭載されている).

(2) source journal は定期刊行物から選ばれており, 国際会議の Proceedings は入っていない.

(3) Corporate Index(Annual volume)は翌年の秋に 発行されるので, 時期的に遅れる.

時期的な遅れの点は, iSi が行っている個別サービス の 1 つである ASCA (Automatic Subject Citation Alert) を利用すれば，毎週，関連情報の printoutを入手でき るので解決する. ASCA は, 特定の研究主題を前もっ て登録しておき，それに関連する論文の情報を敏速に提 供することを目的として始められたものである。 Garfieldによれば, 当初の目的に沿った利用は少なく, 研究管理者や図書館職員が “研究主題” の代わりに“研 究機関名”を登録してASCA サービスを受け，当該研 究機関の論文発表活動の把握に利用している例が多いと のことである(4).

Corporate Index の第 2 の部分, Organizaion section には, Geographic section に挙げられた研究機関名をア ルファベット順に配列し，その所在地が記載してある.

\section{（3） Source Index（情報源索引，SI）}

Source Index には Source Journal に揭載された論文, 記事の著者, タイトル, 雑誌名, 巻, 号, 頁が著者のア ルファベット順に整理されている. Citation Index で は，ある論文を誰がどの雑誌で引用しているかはわかる が，その論文のタイトルは不明であり, Source Index を援用して初めて知ることができる。 また文献調査の過 程で“Details will be published later(elsewhere)”など 続報の予告がありながら，それがどの雑誌に発表された かわからない......といらような場合，このSIを利用す ると(それが source journal に発表されたものであるか ぎり)たちどころに判明する……といった使い方もでき る. CI は第 1 著者のみに着目して整理しているが, SI には 10 人までの共著者の氏名が併記してある。第 2 著 者以降すべての共著者(10名を越える場合にもそのすべ てについて)の氏名の項には“see reference”の形で第 1 著者の項を cross-reference してある.

\section{(4) Permuterm Subject Index（回転式主題索引， PI)}

Permuterm (Subject)Index は Source Journal にのっ た論文のタイトルから抽出したキーワードのアルファベ ット順見出しの下に，その論文の著者名を記したもので ある.キーワードは主キーワード (primary term) と限定
語 (co-term)の組合せからなっている. “Permuterm” といら単語は “術語(term)の並べ換え(permutation)” を意味し，複数のらちどれを主たる検索語 (primary term) として検索を開始してもよいことを示している. あらゆる術語が主見出し語になっている訳ではないが， 例えば “behavior”のよらに他の Index では通常はずさ れている term もPIでは主見出し語として扱われてい るし, “methods”, “analysis”などは限定語として利用 できるよらになっている。

PI は論文表題に含まれている術語のみをもとにして 作成されているので，重要な論文が落ちる可能性も多い し, 予期している内容とは全く別の食品工業や生理学な どの文献を探しあて面喰うこともあるが, Chemical Abstractsなど他の抄録誌とは違った味わいがあり，併 用すると効果的であろら。

\section{Journal Citation Reports に見る金属関係学術誌 のデータ}

上に述べたIndex は, 種々の学術雑誌に掲載された 個々の論文についての情報を与えるものである.これに 対して, Journal Citation Reports (JCR)は, ある学術雑 誌に揭載されている論文のすべての引用状況のデータを もとに, その学術雑誌を評価するための各種の数值を算 出し, 整理したものである.以下では, 日本金属学会お よび鉄鋼協会の欧, 和文誌

- Transactions of the Japan Institute of Metals (T JPN I MET) ${ }^{\dagger}$

\section{-日本金属学会誌 (J JPN I MET)}

- Transactions of Iron and Steel Institute of Japan(T IRON STEEL I JPN)

-鉄と鋼 (TETSU TO HAGANE)

ならびに金属関連の著名な学術雑誌について, JCRの 1987年度版市眺めてみることにする。

表 2 は金属関係の 8 誌が, 1987年度に引用された回 数, その他のデータを示している.たとえば, ACTA METALL 誌の論文は7004回引用されており，これは この年度の被引用誌総計 4332 誌中の 204 位にあたる. 被 引用総数が多いことは, その雑誌(に揭載された論文)が よく読まれていることを意味し, 雑誌を評価する際の指 標として意味がある。しかし，この被引用総数は，その 雑誌の創刊以来の全論文を対象とするものであり, 歴史 の古さや掲載論文数の大小に大きく依存する性質のもの

†杂倠誌の略記名はiSiによる。本稿では通常の略記 名(Trans. JIM, Trans. ISIJ) と iSi の略記名を併用 する。

†† 1987年に発行された各種の学術雑誌をもとに得ら れたデータを内容とするもので, 当該年度の翌 年, すなわち1988年秋に刊行されたもの。本稿の 執筆の時点(1989年 8 月)では最新版である. 
表 2 金属関係学術雑誌の JCR データ.

\begin{tabular}{l|c|c|c}
\hline \hline \multicolumn{1}{c|}{ 誌 名 } & $\begin{array}{c}\text { 被引用総数 } \\
\text { (順位) }\end{array}$ & $\begin{array}{c}\text { Impact } \\
\text { factor }\end{array}$ & $\begin{array}{c}\text { Immediacy index } \\
\text { (順位) }\end{array}$ \\
\hline Trans. JIM & $854(1339)$ & 0.955 & $0.215(1076)$ \\
\hline 日本金属学会誌 & $547(1776)$ & 0.295 & $0.023(2979)$ \\
\hline Trans. ISIJ & $651(1600)$ & 0.337 & $0.134(1649)$ \\
\hline 鉄と鋼 & $800(1401)$ & 0.447 & $0.097(2004)$ \\
\hline ACTA METALL & $7004(204)$ & 1.964 & $0.480(303)$ \\
\hline SCRIPTA METALL & $2465(592)$ & 1.008 & $0.120(1782)$ \\
\hline METALL TRANS A & $3503(439)$ & 1.183 & $0.301(700)$ \\
\hline METALL TRANS B & $776(1428)$ & 1.000 & $0.152(1495)$ \\
\hline
\end{tabular}

で，相互比較に用いるには適当ではない。このため， Impact factor と呼ばれる量が以下のように定義される. たとえば，Trans. JIMの被引用状況の内訳は以下の通 りである。

〈CITATIONS IN 1987 TO $\cdots\rangle$

$\begin{array}{rrrr}\text { ALL YEARS } & 1986 & 1985 & 86+85 \\ 854 & 105 & 85 & 190 \\ \langle\cdots \text { SOURCE } & \text { ITEMS IN }\rangle & \\ 1986 & 1985 & 86+85 \\ 98 & 101 & 199\end{array}$

すなわち，本会欧文誌の1986，1985年に発行された計 24 冊渇載された論文総数は $199(=98+101)$ 篇であり, 1987 年中のこれらの論文に対する延引用回数は $190(=105+85)$ 回である. Impact factor はこの $2 つ の$ 数から $190 / 199=0.955$ となる。表 1 にこの数值を併せ て示した。上の定義から明らかであるよらに, impact factor は, その雑誌に揭載された論文が 1 年間のらちに 他の論文 (他の研究者の論文とは限らない!)によって引 用された回数の平均值であり，その值が高いほど「よく 読まれ，したがってょく引用されている雑誌」と考えて よいであろう。

表 2 の最後の欄に示した Immediacy indexは，その 雑誌に発表された論文がどれだけ速く他の論文により引 用されたかを示す指標である。本会欧文誌の場合， 1987年に発行された 12 冊の総論文数は90，1987年中の これらの論文に対する延引用数は 20 であり，20/ $90=0.215$ が Immediacy index である. 当然のことなが ら, 年明け早々の号に出た論文はその年内に引用される 機会が多く，12月号に出た論文はまず引用されること はないであろう。また，同一著者，グループによる引用 が多数を占めている可能性もあり，この指標にどれほど 意味があるかよくわからない。しかし，一般自然科学誌 である NATURE, SCIENCE はそれぞれ3.255(=3792/ 1165), 3.004 (2412/803) と高い值を示して打り，これら の雑誌の記事が広く研究者の関心をあつめ, 敏速な反応
があることを示唆しているのはうなづけるところであ る.

JCR では，広汎な分野の学術雑誌を約 130 のカテゴリ 一に分類し，それぞれについて Impact factor の順に並 ベたランキングを掲載している。表 3 に“Metallurgy \& Mining”, “Materials Science”, “Materials Science, Ceramics”, “Physics, Applied” のランキングを揭げる. INT J RAPID SOLIDIF など2つのカテゴリーに重複 して分類されているものもある.

表 3 金属関係学術雑誌のランキング.

METALLURGY \& MINING
RANK

J PHYS F MET PHYS
ACTA METALL
MAR MINING
METALL TRANS A
INT J RAPID SOLIDIF
SCRIPTA METALL
OXID MET
METALL TRANS B
T JPN I MET
J LESS-COMMON MET
HYDROMETALLURGY
J NUCL MATER
INT J COAL GEOL
Z METALLKD
GEOEXPLORATION
CORROS SCI
CORROSION
INT J POWDER METALL
WERKST KORROS
INT J ROCK MECH MIN
J MET
TETSU TO HAGANE
STEEL RES
POWDER METALL
SCAND J METALL
IRONMAK STEELMAK
STAHL EISEN
SURF COAT TECH
T IRON STEEL I JPN
MATER SCI TECH SER
T I MIN METALL B
METALLOGRAPHY
PLAT SURF FINISH
J JPN I MET
POWDER METALL INT
CAN METALL QUART
INT J MINER PROCESS
MEM ETUD SCI REV MET
FIZ MET METALLOVED+
CIM BULL
WELD J
IND LAB-USSR+
ARCH EISENHUTTENWES
TECH MITT KRUPP FORS
STEEL USSR
MET SCI HEAT TREAT+
AUTOMAT WELD+
RUSS METALL+
WELD PROD+

IMPACT CITED FACTOR HALF

$\begin{array}{rr}2.080 & 5.8 \\ 1.964 & 8.7 \\ 1.647 & \\ 1.183 & 5.7 \\ 1.067 & \\ 1.008 & 4.8 \\ 1.000 & 7.9 \\ 1.000 & 5.7 \\ 0.955 & 6.9 \\ 0.818 & 5.0 \\ 0.718 & 4.6 \\ 0.706 & 5.3 \\ 0.674 & 3.3 \\ 0.672 & >10.0 \\ 0.667 & \\ 0.663 & 9.3 \\ 0.619 & 8.7 \\ 0.581 & \\ 0.552 & 7.7 \\ 0.500 & 8.1 \\ 0.500 & 6.8 \\ 0.447 & 5.0 \\ 0.410 & \\ 0.393 & 8.5 \\ 0.358 & 8.3 \\ 0.356 & 6.4 \\ 0.344 & 5.0 \\ 0.340 & \\ 0.337 & 5.0 \\ 0.324 & 2.2 \\ 0.321 & 8.0 \\ 0.304 & 8.1 \\ 0.296 & 8.7 \\ 0.295 & 7.7 \\ 0.260 & 7.5 \\ 0.250 & 9.7 \\ 0.234 & 5.8 \\ 0.223 & >10.0 \\ 0.217 & 8.9 \\ 0.188 & 7.3 \\ 0.165 & 10.0 \\ 0.149 & 8.2 \\ 0.111 & 10.0 \\ 0.091 & \\ 0.028 & 8.5 \\ 0.024 & 8.6 \\ 0.014 & \end{array}$


第 12 号 学術雑誌のランキング—Science Citation Index, とくに Journal Citation Reports について一 991

\section{MATERIALS SCIENCE}

RANK

TITLE

ANNU REV MATER SCI
PROG MATER SCI
INT MATER REV
THIN SOLID FILMS
J MAGN MAGN MATER
J BIOMED MATER RES
MATER SCI ENG
INT J RAPID SOLIDIF
MATER RES BULL
J MATER SCI
J ELASTICITY
SOL ENERG MATER
J COMPOS MATER
MATER LETT
MATER CHEM PHYS
WERKST KORROS
J THERM ANAL
J AM CONCRETE I
J MATER SCI LETT
CEMENT CONCRETE RES
WEAR
POLYM COMPOSITE
IEEE T COMPON HYBR
J STRAIN ANAL ENG
J ENG MATER-T ASME
SURF COAT TECH
J SOC DYERS COLOUR
MATER SCI TECH SER
INT J FATIGUE
J FIRE SCI
TEXT RES J
J TEXT I
POLYM TEST
COMPOS SCI TECHNOL
J TEST EVAL
CELL CHEM TECHNOL
IND LAB-USSR+
INORG MATER+
NDT INT
MALC
FACTOR HALF-

$\begin{array}{rr}2.886 & 5.5 \\ 2.222 & 9.6 \\ 1.692 & 6.3 \\ 1.413 & 5.5 \\ 1.410 & 2.7 \\ 1.330 & 7.0 \\ 1.262 & 5.0 \\ 1.067 & \\ 0.858 & 7.7 \\ 0.813 & 6.5 \\ 0.781 & 7.5 \\ 0.761 & 4.7 \\ 0.671 & >10.0 \\ 0.667 & 2.6 \\ 0.621 & 2.6 \\ 0.552 & 7.7 \\ 0.526 & 6.6 \\ 0.522 & >10.0 \\ 0.491 & 2.7 \\ 0.458 & 6.4 \\ 0.432 & 8.3 \\ 0.392 & 3.6 \\ 0.379 & 4.8 \\ 0.368 & >10.0 \\ 0.350 & 8.3 \\ 0.340 & \\ 0.330 & >10.0 \\ 0.324 & 2.2 \\ 0.298 & \\ 0.288 & \\ 0.260 & >10.0 \\ 0.257 & >10.0 \\ 0.250 & \\ 0.222 & \\ 0.173 & 7.2 \\ 0.164 & 8.3 \\ 0.149 & 8.2 \\ 0.078 & 8.4 \\ 0.065 & \\ 0\end{array}$

MATERIALS SCIENCE, CERAMICS

$\begin{array}{ll}1 & \text { PHYS CHEM GLASSES } \\ 2 & \text { J NON-CRYST SOLIDS } \\ 3 & \text { J AM CERAM SOC } \\ 4 & \text { AM CERAM SOC BULL } \\ 5 & \text { GLASS TECHNOL } \\ 6 & \text { GLASTECH BER } \\ 7 & \text { SILIKATY } \\ 8 & \text { BRIT CERAM TRANS J }\end{array}$

1.481

1.411

1.246

0.833

0.281

0.238

0.137

0.114

PHYSICS, APPLIED

\begin{aligned} RANK & \multicolumn{1}{c}{ TITLE } \\ & \\ 1 & IEEE J QUANTUM ELECT \\ 2 & PHILOS MAG B \\ 3 & APPL PHYS LETT \\ 4 & J VAC SCI TECHNOL B \\ 5 & J VAC SCI TECHNOL A \\ 6 & J PHYS F MET PHYS \\ 7 & IEEE T ELECTRON DEV \\ 8 & APPL PHYS A-SOLID \\ 9 & J APPL PHYS \\ 10 & PHILOS MAG A \\ 11 & THIN SOLID FILMS \end{aligned}

IMPACT CITED FACTOR HALF-

$\begin{array}{ll}3.364 & 5.2 \\ 3.260 & 3.3 \\ 3.180 & 4.2 \\ 2.520 & 2.6 \\ 2.126 & 2.4 \\ 2.080 & 5.8 \\ 2.012 & 4.8 \\ 1.970 & 3.3 \\ 1.726 & 7.6 \\ 1.551 & 4.9 \\ 1.413 & 5.5\end{array}$

IMPACT CITED

J LOW TEMP PHYS
METROLOGIA
APPL PHYS B-PHOTO
PLASMA CHEM PLASMA P
INT J THERMOPHYS
J PHYS D APPL PHYS
REV SCI INSTRUM
LASER PART BEAMS
IEEE T MAGN
MATER LETT
INVERSE PROBL
CRYOGENICS
INT J INFRARED MILLI
VACUUM
KVANTOVAYA ELEKTRON +
REV PHYS APPL
ADV ELECTRON EL PHYS
FIZ NIZK TEMP +
JPN J APPL PHYS PT 1
PISMA ZH TEKH FIZ +
VAKUUM-TECH
HIGH TEMP-USSR +
IZV VUZ RADIOFIZ +
ZH TEKH FIZ+

$\begin{array}{ll}1.372 & 7.1 \\ 1.328 & 7.0 \\ 1.215 & 3.8 \\ 1.170 & 4.8 \\ 0.993 & 2.5 \\ 0.987 & 7.2 \\ 0.976 & 8.0 \\ 0.883 & 2.9 \\ 0.760 & 4.6 \\ 0.667 & 2.6 \\ 0.614 & \\ 0.605 & 7.0 \\ 0.585 & 3.2 \\ 0.584 & 5.8 \\ 0.582 & 5.3 \\ 0.518 & 6.7 \\ 0.464 & 8.2 \\ 0.464 & 4.9 \\ 0.437 & 3.1 \\ 0.391 & 4.5 \\ 0.317 & \\ 0.260 & 7.4 \\ 0.248 & 6.7 \\ 0.243 & 8.0\end{array}$

この表にある Cited Half-life は，その雑誌に対する引 用がどの程度古い年度になで及んでいるかを示す指標で ある. 本会欧文誌の論文に対する総引用回数854がどの 年度に発表された論文に対するものであるかを示す内訳 を表 4 に示した．図１には引用回数の累積\%を年度に対 してプロットしてあり,この曲線から, 引用半減期が 6.9年と計算される. 表 3 によれば, ACTA METALL が8.7年, Z METALLKD が 10 年以上で比較的古い論 文まで引用される傾向があるのに対し，2.2年と短い雑 誌もあることが分かる。な拉, INT J RAPID SOLIDIF のように, 創刊後日の浅い雑誌についてはこの值は計算 されていない.

この種のデータを眺めてなんらかの傾向を読みとり判 断を下す際には, 単年度に対する結果のみに着目す

$>10.0$
4.6
9.4
6.0
8.5
$>10.0$
$>10.0$

$>10.0$

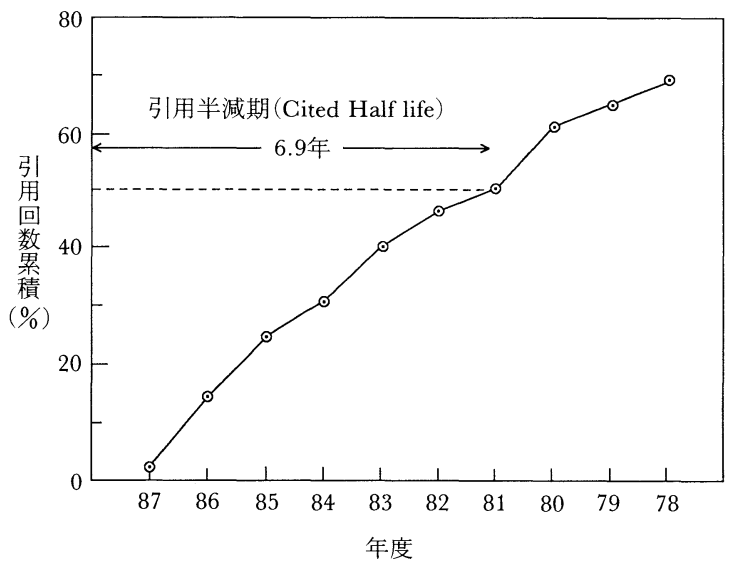

図 1 本会欧文誌の累積引用回数 (\%) と半減期 
表 4 本会欧文誌に対する引用の年度別数.

\begin{tabular}{c|c|c|c|c|c|c|c|c|c|c|c}
\hline \hline 年 度 & 1987 & '86 & '85 & '84 & '83 & '82 & '81 & '80 & '79 & '78 & REST \\
\hline 被引用数(計854) & 20 & 105 & 85 & 53 & 81 & 53 & 33 & 94 & 33 & 36 & 261 \\
\hline 累積被引用数 & 20 & 125 & 210 & 263 & 344 & 397 & 430 & 524 & 557 & 593 & 854 \\
\hline 累積\% & 2.34 & 14.63 & 24.58 & 30.79 & 40.27 & 46.48 & 50.34 & 61.35 & 65.22 & 69.44 & \\
\hline
\end{tabular}

るのは危険であろら。そこで, Metallurgy \& Mining の カテゴリーについて，1983１987年のランキングを表 5 に示した。この表には，1987年のランキングにした がって 1〜20位の雑誌名を並べ, Impact factor と順位, cited half lifeを記した。また，本会と鉄鋼協会の 4 誌 に対するデータをとくに抜き出して，上段に示した。

この分野の雑誌の中では, J. Phys. F と Acta Met. が 不動の 1,2 位を占め続けている.ついで, Metall.

Trans. A, B, Scripta Met., J. Less-Common Met., J. Nucl. Mat.なども比較的高位にある. Trans. JIM は,
学会発行の学術誌(除米国)としてはいい線いっていると いえようか? 一方, 日本金属学会誌の方は平均被引用 回数も $0.2 \sim 0.3$ と低いのは，日本語は日本人しか読まな いためであろらか.

以上のランキングは, Impact factor の数值によるも のであり，引用がどの雑誌によってなされたものである かといら中味については分からない。もしも引用の大部 分が，その論文の揭載誌自体によってなされている (self citation)のであれば，その雑誌は一つの閉鎖社会 を形成していることになろらか？表 6 は，この見地か

表 5 金属分野(Metallurgy \& Mining)の学術雑誌のランキング.

\begin{tabular}{|c|c|c|c|c|c|c|c|c|c|c|c|}
\hline & \multirow[b]{2}{*}{ 誌 } & \multicolumn{2}{|l|}{1983} & \multicolumn{2}{|c|}{1984} & \multicolumn{2}{|c|}{1985} & \multicolumn{2}{|c|}{1986} & \multicolumn{2}{|c|}{1987} \\
\hline & & $\begin{array}{l}\text { Impact } \\
\text { factor }\end{array}$ & $\begin{array}{l}\text { Cited } \\
\text { half- } \\
\text { life }\end{array}$ & $\begin{array}{l}\text { Impact } \\
\text { factor }\end{array}$ & $\begin{array}{l}\text { Cited } \\
\text { half- } \\
\text { life }\end{array}$ & $\begin{array}{l}\text { Impact } \\
\text { factor }\end{array}$ & $\begin{array}{c}\text { Cited } \\
\text { half- } \\
\text { life }\end{array}$ & $\begin{array}{l}\text { Impact } \\
\text { factor }\end{array}$ & $\begin{array}{c}\text { Cited } \\
\text { half- } \\
\text { life }\end{array}$ & $\begin{array}{l}\text { Impact } \\
\text { factor }\end{array}$ & $\begin{array}{l}\text { Cited } \\
\text { half- } \\
\text { life }\end{array}$ \\
\hline \multirow{4}{*}{$\begin{array}{l}\text { 国 } \\
\text { 内 } \\
\text { 誌 }\end{array}$} & Trans. JIM & $0.680(14)$ & 6.0 & $0.984(7)$ & 5.3 & $0.677(17)$ & 6.7 & $0.559(19)$ & 6.6 & $0.955(9)$ & 6.9 \\
\hline & 日本金属学会誌 & $0.185(36)$ & 8.5 & $0.203(40)$ & 7.2 & $0.251(39)$ & 7.8 & $0.225(39)$ & 8.0 & $0.295(34)$ & 7.7 \\
\hline & Trans. ISIJ & $0.475(20)$ & 5.5 & $0.516(18)$ & 4.8 & $0.503(25)$ & 4.6 & $0.368(27)$ & 4.8 & $0.337(29)$ & 5.0 \\
\hline & 鉄之鋼 & & & & & $0.683(16)$ & 3.9 & $0.692(14)$ & 4.4 & $0.447(22)$ & 5.0 \\
\hline \multirow{20}{*}{$\begin{array}{c}\text { 上 } \\
\text { 位 } \\
20 \\
\text { 誌 } \\
\text { 1987 } \\
\text { 年 } \\
\text { 順 } \\
\text { 位 } \\
\text { に } \\
\text { よ } \\
\text { る }\end{array}$} & J PYS F MET PHYS & $2.237(1)$ & 4.8 & $2.408(1)$ & 4.7 & $2.107(1)$ & 5.2 & $2.057(1)$ & 5.3 & $2.080(1)$ & 5.8 \\
\hline & ACTA METALL & $2.073(2)$ & 9.6 & $2.116(2)$ & 9.3 & $1.950(2)$ & 9.0 & $1.960(2)$ & 8.6 & $1.964(2)$ & 8.7 \\
\hline & MAR MINING & & & & & $1.087(6)$ & & $0.882(10)$ & & $1.647(3)$ & \\
\hline & METALL TRANS A & $1.393(3)$ & 4.6 & $1.153(5)$ & 5.0 & $1.268(4)$ & 5.0 & $1.104(5)$ & 5.8 & $1.183(4)$ & 5.7 \\
\hline & INT J RAPID SOLIDIF & & & & & $0.200(42)$ & & $1.278(3)$ & & $1.067(5)$ & \\
\hline & SCRIPTA METALL & $1.028(7)$ & 4.8 & $0.834(12)$ & 4.9 & $0.896(9)$ & 4.9 & $0.922(8)$ & 5.0 & $1.008(6)$ & 4.8 \\
\hline & OXID MET & $0.474(21)$ & 6.8 & $0.928(8)$ & 7.3 & $0.770(14)$ & 7.5 & $0.677(15)$ & 8.0 & $1.000(7)$ & 7.9 \\
\hline & METALL TRANS B & $1.073(6)$ & 4.6 & $1.130(6)$ & 4.9 & $1.065(7)$ & 5.1 & $1.043(6)$ & 5.4 & $1.000(8)$ & 5.7 \\
\hline & T JPN I MET & $0.680(14)$ & 6.0 & $0.984(7)$ & 5.3 & $0.677(17)$ & 6.7 & $0.559(19)$ & 6.6 & $0.955(9)$ & 6.9 \\
\hline & J LESS-COMMON MET & $1.002(8)$ & 5.4 & $1.281(4)$ & 5.6 & $1.179(5)$ & 5.9 & $0.907(9)$ & 5.9 & $0.818(10)$ & 5.0 \\
\hline & HYDRO METALLURGY & $0.907(1.0)$ & 3.7 & $0.872(9)$ & 3.6 & $0.888(10)$ & 3.7 & $0.970(7)$ & 3.8 & $0.718(11)$ & 4.6 \\
\hline & J NUCL MATER & $1.157(4)$ & 4.8 & $1.323(3)$ & 4.3 & $1.310(3)$ & 4.8 & $1.139(4)$ & 4.8 & $0.706(12)$ & 5.3 \\
\hline & INT J COAL GEOL & $0.429(23)$ & & $0.429(25)$ & & $1.056(8)$ & & $0.857(11)$ & & $0.674(13)$ & 3.3 \\
\hline & Z METALLKD & $0.807(12)$ & $>10.0$ & $0.839(11)$ & 9.9 & $0.707(15)$ & $>10.0$ & $0.620(16)$ & $>10.0$ & $0.672(14)$ & $>10.0$ \\
\hline & GEO EXPLORATION & $0.167(38)$ & & $0.436(24)$ & & $0.489(26)$ & 7.6 & $0.360(29)$ & & $0.667(15)$ & \\
\hline & CORROS SCI & $0.965(9)$ & 7.6 & $0.663(15)$ & 8.2 & $0.882(11)$ & 8.9 & $0.789(13)$ & 8.6 & $0.663(16)$ & 9.3 \\
\hline & CORROSION & $0.891(11)$ & 8.5 & $0.789(14)$ & 8.9 & $0.774(13)$ & 8.1 & $0.593(17)$ & $>10.0$ & $0.619(17)$ & 8.7 \\
\hline & INT J POWDER METALL & $0.156(40)$ & & $0.313(33)$ & 7.9 & $0.321(34)$ & & $0.426(23)$ & 8.5 & $0.581(18)$ & \\
\hline & WERKST KORROS & $0.625(15)$ & 6.9 & $0.645(16)$ & 6.6 & $0.513(24)$ & 7.9 & $0.411(25)$ & 8.8 & $0.552(19)$ & 7.7 \\
\hline & INT J ROCK MECH MIN & $0.547(18)$ & 6.2 & $0.455(21)$ & 7.6 & $0.462(27)$ & 7.5 & $0.459(22)$ & 8.3 & $0.500(20)$ & 8.1 \\
\hline
\end{tabular}


12 号 学術雑誌のランキング—Science Citation Index, とくに Journal Citation Reports について一 993

表 6 Citationの中味一どの雑誌によって引用されたか一(SCI Cited Journal Listing より).

\begin{tabular}{|c|c|c|c|c|c|}
\hline \multicolumn{6}{|l|}{ (cited journal) } \\
\hline $\begin{array}{l}\text { T JPN I MET } \\
\text { (citing journal) }\end{array}$ & 854 & T IRON STEEL I JPN & 651 & ACTA METALL & 7004 \\
\hline T JPN I MET & 119 & T IRON STEEL I JPN & 223 & ACTA METALL & 1333 \\
\hline J JPN I MET & 81 & TETSU TO HAGANE & 98 & SCRIPTA METALL & 527 \\
\hline ACTA METALL & 47 & STEEL RES & 40 & MATER SCI ENG & 502 \\
\hline J MATER SCI & 44 & STAHL EISEN & 29 & METALL TRANS A & 459 \\
\hline METALL TRANS A & 43 & MATER SCI TECH SER & 21 & J MATER SCI & 252 \\
\hline SCRIPTA METALL & 37 & METALL TRANS A & 21 & Z METALLKD & 197 \\
\hline J JPN I MET & 547 & TETSU TO HAGANE & 800 & METALL TRANS A & 3503 \\
\hline T JPN I MET & 127 & T IRON STEEL I JPN & 522 & METALL TRANS A & 659 \\
\hline T IRON STEEL I JPN & 72 & STEEL RES & 26 & ACTA METALL & 345 \\
\hline SCRIPTA METALL & 39 & ANAL CHEM & 19 & MATER SCI ENG & 297 \\
\hline METALL TRANS A & 24 & MATER SCI TECH SER & 19 & SCRIPTA METALL & 293 \\
\hline ACTA METALL & 19 & METALL TRANS B & 19 & MATER SCI TECH SER & 162 \\
\hline J MATER SCI & 18 & METALL TRANS A & 17 & J MATER SCI & 117 \\
\hline
\end{tabular}

ら citation の内訳(多い順から8 誌だけ記す)を示したも のである. 国内各誌について self citation(姉妹誌分も含 めて)の割合 (self-cited rate)を計算してみると下記のよ らになる。

$$
\begin{array}{ll}
\text { Trans. JIM } & 0.234(=(119+81) / 200) \\
\text { 日本金属学会誌 } & 0.232(=127 / 547) \\
\text { Trans. ISIJ } & 0.493(=(223+98) / 651) \\
\text { 鉄と鋼 } & 0.653(=522 / 800)
\end{array}
$$

和文の 2 誌の場合, 自誌による引用は少なく 6 以下で JCRにも記されていない)すべて姉妹誌である欧文誌に よる引用分を用いて上記の值を計算した，鉄と鋼の場合 には, Trans. ISIJによる引用が全体の 6 割 5 分を占 め, これが Impact factor の值にも反映していることが わかる十

\section{Journal Citation Reports の構成}

前章では金属関係学術誌の評価といら視点から， JCR で用いられている各種の指標の定義を解説し, 関 連データを眺めてきた。本章では, 自から JCR を手に とって眺めてみよらとする方々のために, 改めて JCR の構成を説明しておくことにしょう。

先にものベたように, Science Citation Index の Annual volume 全20巻のうち, 最後の 2 冊が Journal Cita-

† 鉄鋼協会では春秋の大会の講演概要集に「鉄と鋼」 の通常号をあてており，iSi では各概要を通常の“論 文”とみなして処理していたよらである。李た，欧 文誌である Trans. ISIJ には，これらの講演概要の 一部について，その英文版を揭載してきた。この英 文概要は「鉄と鋼」に揭載された対応する和文概要 を引用しているので, Trans. ISIJ による「鉄と鋼」 の引用回数が高い值を示す結果になっている.

なお，1988年以降，講演概要集は「鉄と鋼」と は独立なものとして発行されるよらになったので, 今後は Journal Citation Reportsに揭載される各種 の統計数值も大幅に変ってくるであろう. tion Reports である.

Volume 19

- Introduction

JCR の目的, 性格, 用語の定義, 構成の解説.

- Sample Displays and Descriptions

Vol. 19, 20 に掲載されている各種の listing の読み方 の説明

- Reprints

Science, Current Contents ぞに掲載された, JCR の意義, 利用の具体例, 問題点を論じたエッセイなど を再録.

- Bibliography

Journal citation analysis とその応用に関する論文の リスト。

- Journal List-Abbreviated to Full-Titles of Citing/ Cited Journals

雑誌名の略称と正規名称の一覧表

- Journal Rankings

$\diamond$ Section 1 SCI Journals in Alphabetical Order

$\diamond$ Section 2 Journals Ranked by Times Cited in 1987

$\diamond$ Section 3 Journals Ranked by Impact Factor $\diamond$ Section 4 Journals Ranked by Immediacy Index $\diamond$ Section 5 Journals Ranked by Source Items

$\diamond$ Section 6 Journals Ranked by Times 1985 and 1986 Items Were Cited in 1987

$\diamond$ Section 7 SSCI Journals in Alphabetical Order

$\diamond$ Section 8 SCI Journals by Category Ranked by Impact Factor

$\diamond$ Section 9 SCI Journal Category Listing

以上 9 つの Section のうち, Section $1 \sim 6$ は全く同一の 内容の表であり, 着目する量によって雑誌名の配列順序 が変わっているにすぎない，ある雑誌について調べる際 
には，誌名のアルファベット順に配列されている Section 1 を用いれば, 被引用回数, Impact factor, Immediacy indexなどの值を知ることがでさる。これらの 量の各々に着月して全体の中での順位を知りたいときに はSection 2〜6 を参照する. Section 7 は Social Science Citation Index(SSCI) といら iSi が刊行している他の索 引誌の対象となっている社会科学関係の雑誌名リストで ある．学際化の進行によって相互に引用される場合もあ ることから，このリストが加えられている。

Section 8,9 は前章で示したカテゴリ一別ランキング に関するもので，ある雑誌の属するカテゴリーはSection 9 を参照して知ることができる. 表 3 は Section 8 から抜粋したものである.

\section{Source Data Listing}

このリストには，雑誌がアルファベット順に配列さ れ，その年度に掲載された論文総数，各論文の引用文献 数の総和, 1 論文あたりの引用文献数の平均值が記され ている．学問分野によって引用数は大幅に異なり，「生 化学では 30 以上, 数学では $10 か ゙$ 平均の引用文献数」との ことである. したがって, 生化学分野の論文は数学分野 の論文より Impact factor が大きくなる傾向が予想され よう.

またこのリストでは, non-review airticle と review articleに分類して上記の数值を記している。ここで review article とは次のいずれかを満たすものと定義さ れている.

（1）引用文献数が 100 以上である論文.

(2) review articleのみを揭載する journalにのった 論文.

（3）“review section”に揭載された論文.

(4) 論文のタイトルに Review むしくは Overviewと いら語が含まれている論文.

（5）その論文の Summary で，“これは review（もし くは survey)である”とのべている論文.

このリストをみることによって，どの雑誌が reviewを 年間どの位の数掲載しているか知ることができる．良い review article は頻繁に引用されるであろらから，その 雑誌の被引用回数も高くなる傾向がある.

\section{$\bullet$ Journal Half-Life Listing}

$\nabla$ Section 1-Cumulative Chronological Distribution of Citations from Citing Journals

$\nabla$ Section 2-Cumulaltive Chronological Distribution of Citations to Cited Journals

$\nabla$ Section 3-Journals Ranked by Half-Life 前章では, 被引用回数 (cited)の年度別変化と cited halflifeについて説明した，上記の Section 2 には，表 4 の 累積\%(最下欄)に相当する数值が各雑誌に対して与えら れている.

これに対して，ある雑誌に掲載されている論文があげ
ている (citing) reference の年度別分布を与えているの が Section 1 である。「若い年度の文献を多く引用して いる雑誌汪ど, 若々しくて活力がある」？ということ になるのかどらか, SCIの解説もこの Listing の意義, これから定義される Citing Half-Life の意味には触れて いない.

\section{$\diamond$ Citing Journal Listing}

Volume 20

\section{$\checkmark$ Cited Journal Listing}

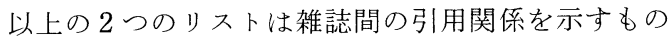
で, 表 6 は Cited Journal Listing のデータをもとに構 成した。Citing Journal Listing は，ある雑誌の論文が 引用している(citing) 文献を揭載雑誌別, 年度別に整理 したものである。

\section{Journal Citation Reports をどう利用するか?}

JCR は Science Citation Index の創始者, E. Garfield が始めたもので, 科学の社会的機能を論じた英国の物理 学者 J. D. バーナルに触発されるところがあったらしい. JCR は1975年版以降の SCI の一部として独立な巻を構 成している。その効用，利用に関して Garfield 自身の 文章(5)を引用しつつのべてみよう。

JCR は以下のような種類の質問に即座に回答を与え る.

『ある特定の雑誌はどの位引用されているか？

齐染誌がそれを引用しているか？

佣されている論文は新しいものか古いものか？

なぜこんな質問をする必要があるかと思う人も居るで あろう。こんな質問に答えるために時間と金をかける值 打ちがそもそもあるのであろらか？ 誰がその答えを欲 し, 必要とするのであろらか? 雑誌を比較したり，そ の重要性を評価することがなぜ必要なのか？ 雑誌が発 行され財政的にも成り立っているという事実とのものが 何よりも雄弁にものがたっているではないか！雑誌は それを必要とする人々がいるからこそ発行されているの だ.——残念ながら，世の中それほど簡単ではない。

学術雑誌刊行の経済ならびに政治的側面は非常に複雑 でここで立入ることはしないが，単純な経済原理 (authoritative voice of economics)によって支配されて いるものでないことは明言できる．雑誌の経費は学会や 政府の補助金, 投稿者の支払らページ・チャージ，広告 料に多分に依存しているからである。実は，だからこそ 上に挙げたよらな質問に答える必要があるといえよう。

図書館の運営に責任ある人は, 限られた予算でどの雑 誌を購入すべきか, 古くから購入している雑誌を継続す べきか否かの判断を下す際に, JCRのデータを客観的 
な指標として用いることがでさよう。限られた書棚に並 べて置くもの，倉庫にしまいこもものの区分けをするた めには cited half-life などの数值をめやすにすることが できる†.

雑誌の編集 · 刊行の責任者にとっては, その雑誌が当 該分野においていかなる位置を占めているかを知り, 編 集方針を決定する上で JCR の各種の指標が参考になる.

Impact factor がきわめて低い雑誌は，JCR の対象誌 になっていない, Garfieldのもとには, “是非, 対象誌 に加えてほしい”といら陳情が雑誌の編集者から数多く よせられているそうである(5)

\section{6. おわりに}

以上, Science Citation Index の概要と Journal Citation Reportsについてのべた. SCIの利用に関する様々 な問題点については，以前本誌に執筆した(6)ので参照し ていただきたい.SCI は多くの大学の中央図書館等で購 入しているので，積極的に利用されることを打すすめし たい、筆者は，大学院の講義の時間の一部をさいて SCI の概要を説明し, 個々の学生の研究テーマに関する 主要論文について， citationの状況を調べることを演習 として課している。なお， SCI は磁気テープの形でも提

†これらの判断を下す際には，当然のことながら個々 の図書館に打ける利用状況が最優先に考慮されるべ きである。もっとも単純な利用状況の判定法は，製 本雑誌に汪こりがつもってないか！背表紙にひび が入っていないかどらかである(T. E. Smith: the Bulletin of the Medical Library Association, Vol. 73 (4), October 1985 より).
供されており，LOKHEED DIALOG，学術情報センタ 一などの文献情報検索サービスを行っている機関のデー タベースの 1 つとして利用可能である。 また，最近では Compact Disc 版も発行されている(ただし，JCRはこ れら計算機可読の形にはまだなっていない).

Journal Citation Reports は，学会誌の評価をする上 で種々の興味ある情報を提供してくれる．本会欧文誌は， 1987年度のデータを見るかぎり一応の水準を維持して いると考えてよいであろら，その声価をさらに高めるた めに，レベルの高い論文が数多く投稿されることを望み たい.

本稿を執筆するに際して，iSi および日本販売総代理 店ユサコ株式会社 (東京都港区新橋 1 丁目 13 番 2 号堤ビ ル)より資料の提供をいただいた。ここに記して謝意を 表する.

\section{文献}

（1）小岩昌宏：“Science Citation Indexについて”，日本 金属学会会報, 14(1975), 203.

（2）小岩昌宏：“ポインティング効果の話”，日本金属学 会会報, 21 (1982), 210 .

（3）小岩昌宏：“相変化の速度論の系譜”, 日本金属学会 会報, 25(1986), 640 .

(4) E. Garfield: "ASCA can help you monitor publication in your organization or country", Current Contents (39): 5-8, 25 September 1978.

( 5 ) E. Garfield: "How to use Journal Citation Reports", Current Contents (17): 5-12, 25 April, 1983.

（6）小岩昌宏： “Science Citation Index の功罪一米国の 材料系学科の評価をめぐって一”, 日本金属学会会報, 22 (1983), 1055. 